
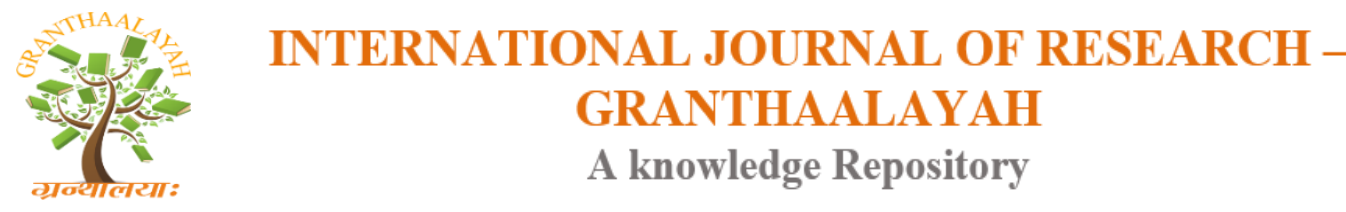

Science

\title{
EVALUATION OF TOMATO RESPONSE TO DEFICIT IRRIGATION AT HUMBO WOREDA, ETHIOPIA
}

\author{
Tamirneh Kifle ${ }^{* 1}$ \\ ${ }^{* 1}$ Department of Irrigation, Southern Agricultural Research Institute, Areka Agricultural \\ Research Center, Areka, Ethiopia
}

\begin{abstract}
Water scarcity, erratic rainfall distribution and better management of water are the most sever constraint for the development of agriculture. To cope with scarce supplies, deficit irrigation is an important tool to achieve the goal of reducing irrigation water use and increase water use efficiency (WUE) under scarce water resources. This research was carried out at Southern Agricultural Research Institute of Areka Agricultural Research Center of Hubo Woreda in farmers' fields during 2016/2017-2017/2018 to identify the level of deficit irrigation which allow achieving optimum Tomato yield. The experimental design was arranged in RCBD with four treatments with three replications. The irrigation treatments were $100 \%$ ETc, $85 \%$ ETc, $75 \%$ ETc and $50 \%$ ETc. The result showed that a maximum fruit yield of 43.4 ton/ha was obtained under full irrigation. A deficit irrigation strategy applied at $85 \%, 70 \%$ of crop water requirement gives relatively better fruit yield i.e. 34.2 ton/ha and 32.1 ton/ha. For Tomato in water scarce area applying $85 \%$ and $70 \%$ of crop water requirement is recommended with a minimum reduction of yield.
\end{abstract}

Keywords: Deficit Irrigation; Etc; Tomato; RBCD; Water Use Efficiency.

Cite This Article: Tamirneh Kifle. (2018). "EVALUATION OF TOMATO RESPONSE TO DEFICIT IRRIGATION AT HUMBO WOREDA, ETHIOPIA." International Journal of Research - Granthaalayah, 6(8), 57-68. 10.29121/granthaalayah.v6.i8.2018.1262.

\section{Introduction}

In the semi-arid areas of Ethiopia, water is the most limiting factor for crop production. In these areas where the amount and distribution of rainfall is not sufficient to sustain crop growth and development, an alternative approach is to make use of the rivers and underground water for irrigation. Satisfying crop water requirements, although it maximizes production from the land unit, does not necessarily maximize the return per unit volume of water (Oweis et al, 2000).

To quantify the level of deficit irrigation it is first necessary to define the full crop ET requirements. Fortunately, since Penmann (1948) developed the combination approach to calculate ETo, research on crop water requirements has produced several reliable methods for its calculation. At present, 
the Penman-Monteith equation (Allen et al., 1998) is the established method for determining the ETo of the major herbaceous crops with sufficient precision for management purposes.

Under conditions of scarce water supply, application of deficit irrigation deficit irrigation could provide greater economic returns than maximizing yields per unit of water. The deficit irrigation has been considered worldwide as a way of maximizing water use efficiency (WUE) by eliminating irrigation that has little impact on yield (English, 1990). With deficit irrigation, the crop is exposed to a certain level of water stress either during a particular period or throughout the whole growing season (Kirda, 2000).

Deficit irrigation is one of the irrigation water management practices which are not necessarily based on full water required by the crops. It is an optimization strategy whereby net returns are maximized by reducing the amount of irrigation water and crops are deliberately allowed to sustain some degree of water deficit with insignificant yield reduction (Capra et al, 2008).

Deficit irrigation increases the productivity of water in agriculture and plays a very important role in reducing competition for scarce water resources, minimizing environmental degradation and provision of food security. However, the amount of irrigation water reduction is based on crop characteristics and generally accompanied by no or insignificant yield loss that increases the water productivity (Ahmadi et al., 2010). The objective of this research is to identify the level of deficit irrigation which allows achieving optimum Tomato yield maximum net income.

\section{Materials and Methods}

\subsection{Study Area Description}

Field experiment was conducted over a two-year period under Areka Agricultural Research Center, Humbo Woreda from January to April of 2016 - 2018. The study site was located at latitude $06^{0} 44^{\prime} \mathrm{N}$, longitude $037^{0} 48^{\prime} \mathrm{E}$ and an altitude 1611 metere above sea level as shown in Figure 1. The experimental area has an arid climate with cool winter and hot dry summer.

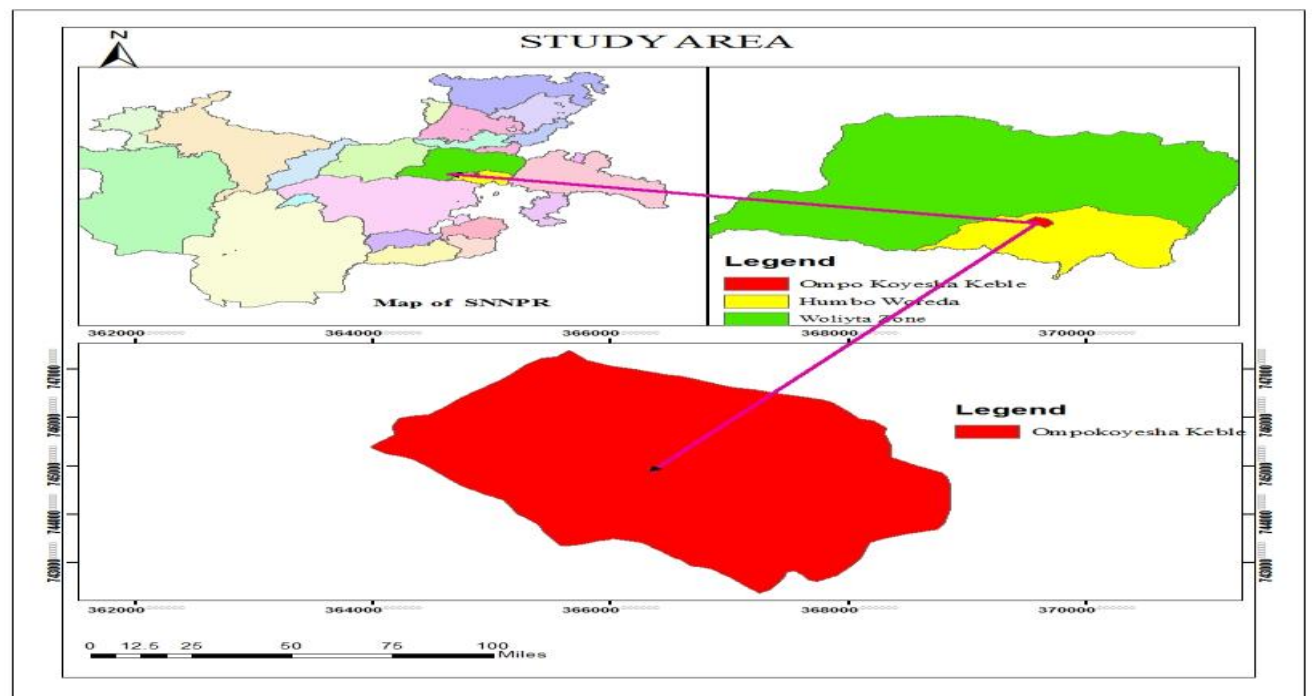

Figure 1: Location Map of Ompokoyesha Kebele of Humbo Woreda 


\subsection{Soil Physical and Chemical Properties}

The soil of experimental site is classified as clay soil. Some physical and chemical properties of the experimental soil are presented in Table 1. The study site soil has average bulk density $1.26 \mathrm{~g} / \mathrm{cm}^{3}, \mathrm{pH} 5.96$ and electric conductivity $1.258 \mathrm{ds} / \mathrm{m}$.

\subsection{Experimental Design and Treatments}

The experiment was laid out in randomized complete block design with three replications of four level treatments. The treatment was conducted under furrow irrigation method. The amount of irrigation water to be applied at each irrigation application was measured using Parshall flume. The treatments were $100 \% \mathrm{ETc}, 85 \% \mathrm{ETc}, 70 \% \mathrm{ETc}$ and $50 \% \mathrm{ETc}$. The experimental field was divided into 12 plots and each plot size was $4 \mathrm{~m}$ by $5 \mathrm{~m}$ dimension. Space between rows and the plants were $90 \mathrm{~cm}$ and $30 \mathrm{~cm}$ respectively.

\subsection{Crop Data}

Maximum effective root zone depth (RZD) of tomato ranges between 0.7-1.5m and has allowable soil water depletion fraction (P) of 0.40(Andreas et al., 2002). Tomato average Kc would be taken after adjustments have been made for initial, mid and late season stage to be 0.6, 1.15 and 0.8, respectively (Allen et al., 1998). Yield data like economical yield, unmarketable yield and total yield was measured in the field.

\subsection{Crop Water Determination}

Crop water requirement refers to the amount of water that needs to be supplied, while crop evapotranspiration refers to the amount of water that is lost through evapotranspiration (Allen et al., 1998). For the determination of crop water requirement, the effect of climate on crop water requirement, which is the reference crop evapotranspiration (ETo) and the effect of crop characteristics (Kc) are important (Doorenbos and pruitt, 1977). The long term and daily climate data such as maximum and minimum air temperature, relative humidity, wind speed, sunshine hours, and rainfall data of the study area were collected to determine reference evapotranspiration, crop data like crop coefficient, growing season and development stage, effective root depth, critical depletion factor of tomato and maximum infiltration rate and total available water of the soil was determined to calculate crop water requirement using cropwat model.

$\mathrm{ETc}=\mathrm{ETo} \times \mathrm{Kc}$

Where, ETc = crop evapotranspiration, $\mathrm{Kc}=$ crop coefficient, ETo = reference evapotranspiration.

\subsection{Irrigation Water Management}

The total available water (TAW), stored in a unit volume of soil was determined by the expression:

$T A W=\frac{(F c-P W P) * B D * D z}{100}$ 
The depth of irrigation supplied at any time can be obtained from the equation

$$
\operatorname{Inet}(\mathrm{mm})=\operatorname{ETc}(\mathrm{mm})-\operatorname{Peff}(\mathrm{mm})
$$

The gross irrigation requirement will be obtained from the expression:

$$
I g=\frac{I n}{E a}
$$

Ea=application efficiency of the furrows (60\%)

The time required to deliver the desired depth of water into each furrow will be calculated using the equation:

$$
t=\frac{d * l * w}{6 * Q}
$$

Where: $d=$ gross depth of water applied $(\mathrm{cm}), \mathrm{t}=$ application time $(\mathrm{min}), \mathrm{l}=$ furrow length in $(\mathrm{m})$, $\mathrm{W}=$ furrow spacing in $(\mathrm{m})$, and $\mathrm{Q}=$ flow rate (discharge) $(\mathrm{l} / \mathrm{s})$

The amount of irrigation water to be applied at each irrigation application was measured using Parshall flume.

\subsection{Data Collection}

Daily climate like maximum and minimum air temperature, relative humidity, wind speed, sunshine hours and rainfall data was collected to calculate crop water requirement. Soil moisture was determined gravimetrically. Amount of applied water per each irrigation event was measured using calibrated pareshall flume. During harvesting Stand count, weight of economical yield, fruit number of economical yield, unmarketable fruit weight and unmarketable fruit number were measured from the net harvested area of each plot.

\subsection{Economic Analysis}

Economic evaluation of deficit irrigation is analyzing the cost that invested during growing season and benefit gained from yield produced by application of water. Marginal Rate of Return (MRR) was used for analysis following the CYMMYT method (CIMMYT, 1988). Economic water productivity was calculated based on the information obtained at the study site: the size of irrigable area, the price of water applied and the income gained from the sale of onion yield by considering the local market price. Yield and economic data were collected to evaluate the benefits of application of different levels of water in deficit irrigation treatments. Economic data includes input cost like cost for water (water pricing), seeds, fertilizers, fuel and labor. However, cost of water pricing and yield sale price were the only cost that varies between treatments. The net income (NI) treatments were calculated by subtracting total cost (TC) from gross income (GI) and were computed as: 


$$
N I=G I-T C
$$

The difference between net income of a treatment and its next higher variable cost treatment termed as change in net income $(\Delta \mathrm{NI})$. Higher net benefits may not be attractive if they require very much higher costs (CIMMYT, 1988). Hence, it is required to calculate marginal costs with the extra marginal net income. The marginal rate of return (MRR) indicates the increase of the net income, which is produced by each additional unit of expenditures and it is computed as follows: Where, $\mathrm{MRR}=$ marginal rate of return, $\Delta \mathrm{NI}=$ change in net income, $\Delta \mathrm{VC}=$ change in variable cost

\subsection{Statistical Analysis}

The collected data were analyzed using Statistical Agricultural Software (SAS 9.0) and least significance difference (LSD) was employed to see a mean difference between treatments and the data collected was statistically analyzed following the standard procedures applicable for RCBD with single factor. The treatment means that were different at $5 \%$ levels of significance were separated using LSD test.

\section{Results and Discussion}

\subsection{Physical and Chemical properties of Soil}

As indicated in Table 1 the average composition of sand, silt and clay percentages were $26.5 \%$, $12 \%$ and $61.5 \%$, respectively. Thus, according to the USDA soil textural classification, the percent particle size determination for experimental site revealed that the soil texture could be classified as clay soil. The top soil surface had slightly lower bulk density $(1.15 \mathrm{~g} / \mathrm{cm} 3)$ than the subsurface $(1.34 \mathrm{~g} / \mathrm{cm} 3)$. The bulk density shows slight decrease with depth. This could be because of slight decrease of organic matter with depth and compaction due to the weight of the overlying soil layer (Brady and Weil, 2002). In general, the average soil bulk density $(1.27 \mathrm{~g} / \mathrm{cm} 3)$ is below the critical threshold level $(1.4 \mathrm{~g} / \mathrm{cm} 3)$ and was suitable for crop root growth.

Average moisture content at field capacity of the experimental site soils were $18.50 \%$ and at permanent wilting point had $15.75 \%$ through one meter soil depth. The total available water (TAW) that is the amount of water that a crop can extract from its root zone is directly related FC and PWP. The representative value of TAW was $238.2 \mathrm{~mm} / \mathrm{m}$ and the TAW range of $190-260$ $\mathrm{mm} / \mathrm{m}$ is the characteristic for clay soil (Brouwer et al., 1985). Soil $\mathrm{pH}$ was found to be at the optimum value (5.96) for tomato and other crops. The value of EC $(1.25 \mathrm{ds} / \mathrm{m})$ was lower considering the standard rates in literature (Landon, 1991). Generally, according to USDA soil classification, a soil with electrical conductivity of less than $2.0 \mathrm{dS} / \mathrm{m}$ at $25^{\circ} \mathrm{C}$ and $\mathrm{pH}$ less than 8.5 are classified as normal soil. Therefore, the soils of the study area are normal soils. The weighted average organic matter content of the soil was about 2.17\%. As cited in Staney and Yerima (1992), the organic matter content of the soil is of medium class. 
Table 1: Characteristics of soil in the experimental area

\begin{tabular}{|c|c|c|c|c|c|c|}
\hline \multirow{2}{*}{\multicolumn{2}{|c|}{ Soil property }} & \multicolumn{5}{|c|}{ Soil depth in (cm) } \\
\hline & & $0-20$ & $20-40$ & $40-60$ & $60-100$ & Average \\
\hline \multirow{3}{*}{$\begin{array}{l}\text { Particle size } \\
\text { Distribution }\end{array}$} & Sand $(\%)$ & 28 & 32 & 24 & 22 & 26.5 \\
\hline & Silt (\%) & 12 & 12 & 12 & 12 & 12 \\
\hline & Clay $(\%)$ & 60 & 56 & 64 & 66 & 61.5 \\
\hline \multicolumn{2}{|c|}{ Textural class } & Clay & Clay & Clay & Clay & Clay \\
\hline \multicolumn{2}{|c|}{ Bulk density (g/cm3) } & 1.15 & 1.26 & 1.32 & 1.30 & 1.26 \\
\hline \multicolumn{2}{|c|}{ FC (Vol \%) } & 18.5 & 18.5 & 18.50 & 18.50 & 18.5 \\
\hline \multicolumn{2}{|c|}{ PWP (Vol \%) } & 15.75 & 15.7 & 15.75 & 15.75 & 15.8 \\
\hline \multicolumn{2}{|l|}{ TAW $(\mathrm{mm} / \mathrm{m})$} & 31.62 & 34.6 & 36.3 & 35.75 & 238.3 \\
\hline \multicolumn{2}{|l|}{ Ph } & 5.9 & 5.97 & 5.99 & 5.96 & 5.96 \\
\hline \multicolumn{2}{|l|}{ EC (ds/m) } & 1.44 & 1.22 & 1.17 & 1.20 & 1.258 \\
\hline \multicolumn{2}{|l|}{ OM (\%) } & 2.8 & 2.2 & 2 & 1.7 & 2.17 \\
\hline \multicolumn{2}{|l|}{$\mathrm{OC}$} & 2.2 & 2.8 & 2.3 & 2.4 & 2.4 \\
\hline
\end{tabular}

The basic infiltration rate in this experiment was found to be $4.8 \mathrm{~mm} / \mathrm{hr}$ which is in the lower range of clay soil (1-5mm/hr) (Hillel, 2004). This means that a water layer of $4.8 \mathrm{~mm}$ on the soil surface will take one hour to infiltrate. In dry soil, water infiltrates rapidly and as more water replaces the air in the pores, the water from the soil surface infiltrates more slowly and eventually reaches a basic infiltration rate.
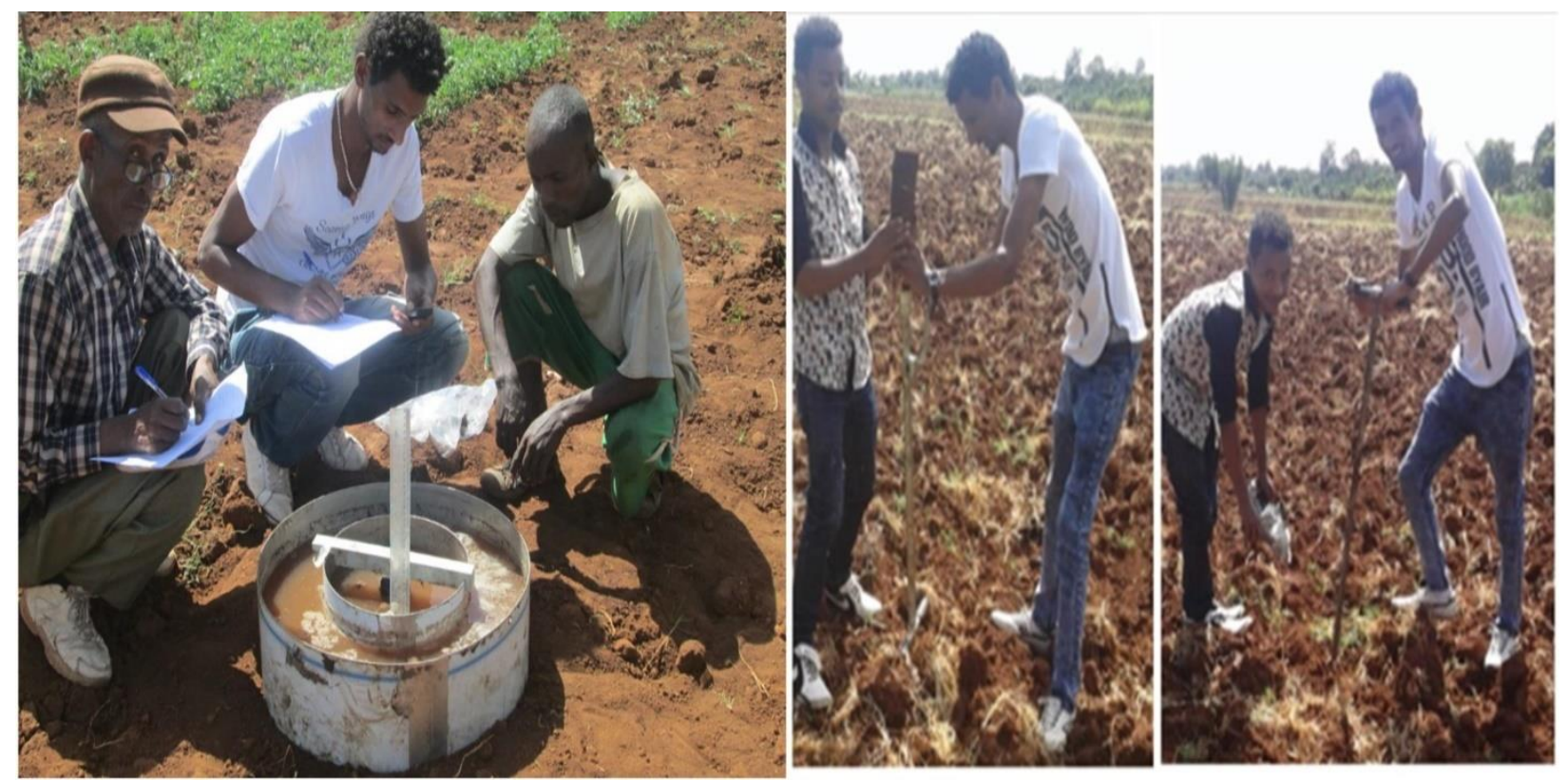

Figure 2: Infiltration Rate Test and Soil Sampling 


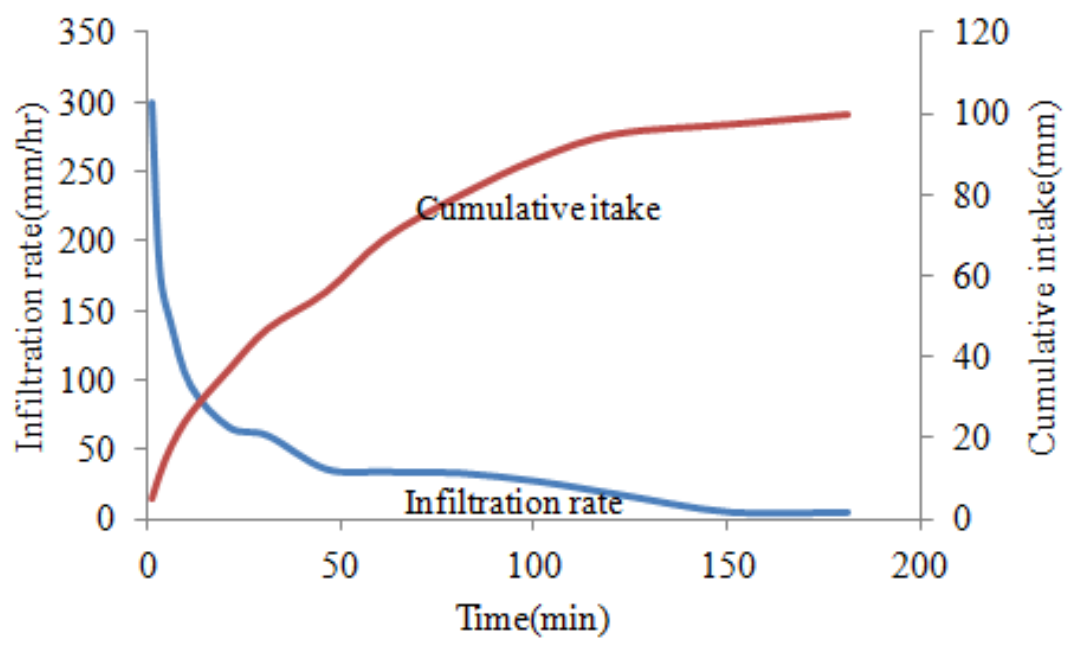

Figure 3: Cumulative intake and infiltration rate curves

Tomato was planted on 01/01/2016/17 and the growth months were (January, February, March and April). The amount of water required by tomato was increasing from initial period to mid period. The maximum irrigation water $(33.6 \mathrm{~mm})$ was required at mid-March of mid stage. In this stage tomato was attained its maximum crop coefficient and there was high reference evapotranspiration. At late period the water required was reduced due to reduction crop coefficient value.

Table 3: Crop and irrigation water requirement for tomato at four days interval

\begin{tabular}{|c|c|c|c|c|c|c|c|}
\hline Date & Stage & Kc & $\begin{array}{c}\text { ETo } \\
(\mathrm{mm} / \text { period })\end{array}$ & $\begin{array}{c}100 \% \\
\text { ETc } \\
(\mathrm{mm} / \text { period })\end{array}$ & $\begin{array}{c}\text { 85\% ETc } \\
(\mathrm{mm} / \text { period })\end{array}$ & $\begin{array}{c}\text { 70\%ETc } \\
(\mathrm{mm} / \text { period })\end{array}$ & $\begin{array}{c}50 \% \text { ETc } \\
(\mathrm{mm} / \text { period })\end{array}$ \\
\hline 4-Jan & Init & 0.6 & 15.8 & 9.48 & 8.05 & 6.63 & 4.74 \\
\hline 8-Jan & Init & 0.6 & 15.8 & 9.48 & 8.05 & 6.63 & 4.74 \\
\hline 12-Jan & Init & 0.6 & 15.8 & 9.48 & 8.05 & 6.63 & 4.74 \\
\hline 16-Jan & Init & 0.6 & 15.8 & 9.48 & 8.05 & 6.63 & 4.74 \\
\hline 20-Jan & Dev & 0.6 & 15.8 & 9.48 & 8.05 & 6.63 & 4.74 \\
\hline 24-Jan & Dev & 0.65 & 15.8 & 10.2 & 8.72 & 7.18 & 5.13 \\
\hline 28-Jan & Dev & 0.72 & 16.84 & 12.12 & 10.30 & 8.48 & 6.06 \\
\hline 1-Feb & Dev & 0.80 & 16.84 & 13.47 & 11.45 & 9.43 & 6.73 \\
\hline 5-Feb & Dev & 0.87 & 16.84 & 14.65 & 12.45 & 10.25 & 7.32 \\
\hline 9-Feb & Dev & 0.95 & 16.84 & 15.99 & 13.59 & 11.19 & 7.99 \\
\hline 13-Feb & Dev & 1.02 & 16.84 & 17.17 & 14.60 & 12.02 & 8.58 \\
\hline 17-Feb & Mid & 1.10 & 16.84 & 18.52 & 15.74 & 12.96 & 9.26 \\
\hline 21-Feb & Mid & 1.15 & 17.52 & 20.14 & 17.12 & 14.10 & 10.0 \\
\hline 25-Feb & Mid & 1.15 & 17.52 & 20.14 & 17.12 & 14.10 & 10.0 \\
\hline 1-Mar & Mid & 1.15 & 17.52 & 20.14 & 17.12 & 14.10 & 10.0 \\
\hline 5-Mar & Mid & 1.15 & 17.52 & 20.14 & 17.12 & 14.10 & 10.0 \\
\hline 9-Mar & Mid & 1.15 & 17.52 & 20.14 & 17.12 & 14.10 & 10.0 \\
\hline 13-Mar & Mid & 1.15 & 17.52 & 20.14 & 17.12 & 14.10 & 10.0 \\
\hline
\end{tabular}


[Kifle *, Vol.6 (Iss.8): August 2018]

(Received: July 05, 2018 - Accepted: August 21, 2018)
ISSN- 2350-0530(O), ISSN- 2394-3629(P)

DOI: 10.5281/zenodo.1403803

\begin{tabular}{|l|l|l|l|l|l|l|l|}
\hline 17-Mar & End & 1.15 & 15.92 & 18.30 & 15.56 & 12.81 & 9.15 \\
\hline 21-Mar & End & 1.15 & 15.92 & 18.30 & 15.56 & 12.81 & 9.15 \\
\hline 25-Mar & End & 1.12 & 15.92 & 17.83 & 15.15 & 12.48 & 8.91 \\
\hline 29-Mar & End & 1.06 & 15.92 & 16.87 & 14.34 & 11.81 & 8.43 \\
\hline 2- April & End & 0.99 & 15.92 & 15.76 & 13.39 & 11.03 & 7.88 \\
\hline 6- April & End & 0.92 & 15.92 & 14.64 & 12.44 & 10.25 & 7.32 \\
\hline 10- April & End & 0.86 & 14 & 12.04 & 10.23 & 8.428 & 6.02 \\
\hline 14- April & End & 0.79 & 14 & 11.06 & 9.401 & 7.742 & 5.53 \\
\hline Total & & 424.48 & 395.3 & 336.0 & 276.7 & 197.6 \\
\hline
\end{tabular}

\subsection{Method of Irrigation}

Irrigation water applied to the experimental plot was done using 3 inch parshall flume at $5 \mathrm{~cm}$ head. The gross amount of water applied to each plot was obtained by multiplying the net irrigation depth of water by application efficiency. The time needed to apply irrigation water for each plot and treatment was showed in the table below.

Table 4: Irrigation water management

\begin{tabular}{|c|c|c|c|c|c|c|c|c|c|c|}
\hline \multirow[t]{2}{*}{ Date } & $\mathrm{T1}$ & T2 & T3 & T4 & \multirow[t]{2}{*}{ Area (m2) } & \multirow{2}{*}{$\begin{array}{c}\text { Discharge } \\
\text { at } 5 \mathrm{~cm} \\
\text { head(l/s) }\end{array}$} & \multirow{2}{*}{\begin{tabular}{c|} 
T1 \\
Time \\
(min)
\end{tabular}} & \multirow{2}{*}{$\begin{array}{c}\text { T2 } \\
\text { Time } \\
(\mathrm{min})\end{array}$} & \multirow{2}{*}{$\begin{array}{c}\text { T3 } \\
\text { Time } \\
\text { (min) }\end{array}$} & \multirow{3}{*}{$\begin{array}{c}\frac{T 4}{\text { Time }} \\
\text { (min) } \\
1.5\end{array}$} \\
\hline & $\begin{array}{c}\text { 100\% IRn } \\
(\mathrm{mm})\end{array}$ & $\begin{array}{c}\text { 85\% IRg } \\
(\mathrm{mm})\end{array}$ & $\begin{array}{l}75 \% \\
\text { IRg } \\
(\mathrm{mm}) \\
\end{array}$ & $\begin{array}{c}\mathbf{5 0 \%} \\
\text { IRg } \\
(\mathrm{mm}) \\
\end{array}$ & & & & & & \\
\hline 4-Jan & 15.8 & 13.4 & 11.1 & 7.9 & 20 & 1.7 & 3.1 & 2.6 & 2.2 & \\
\hline 8-Jan & 15.8 & 13.4 & 11.1 & 7.9 & 20 & 1.7 & 3.1 & 2.6 & 2.2 & 1.5 \\
\hline 12-Jan & 15.8 & 13.4 & 11.1 & 7.9 & 20 & 1.7 & 3.1 & 2.6 & 2.2 & 1.5 \\
\hline 16-Jan & 15.8 & 13.4 & 11.1 & 7.9 & 20 & 1.7 & 3.1 & 2.6 & 2.2 & 1.5 \\
\hline 20-Jan & 15.8 & 13.4 & 11.1 & 7.9 & 20 & 1.7 & 3.1 & 2.6 & 2.2 & 1.5 \\
\hline 24-Jan & 17.1 & 14.5 & 12.0 & 8.6 & 20 & 1.7 & 3.4 & 2.9 & 2.3 & 1.7 \\
\hline 28-Jan & 20.2 & 17.2 & 14.1 & 10.1 & 20 & 1.7 & 4.0 & 3.4 & 2.8 & 2.0 \\
\hline 1-Feb & 22.5 & 19.1 & 15.7 & 11.2 & 20 & 1.7 & 4.4 & 3.7 & 3.1 & 2.2 \\
\hline 5-Feb & 24.4 & 20.8 & 17.1 & 12.2 & 20 & 1.7 & 4.8 & 4.1 & 3.4 & 2.4 \\
\hline 9-Feb & 26.7 & 22.7 & 18.7 & 13.3 & 20 & 1.7 & 5.2 & 4.4 & 3.7 & 2.6 \\
\hline 13-Feb & 28.6 & 24.3 & 20.0 & 14.3 & 20 & 1.7 & 5.6 & 4.8 & 3.9 & 2.8 \\
\hline 17-Feb & 30.9 & 26.2 & 21.6 & 15.4 & 20 & 1.7 & 6.1 & 5.1 & 4.2 & 3.0 \\
\hline 21-Feb & 33.6 & 28.5 & 23.5 & 16.8 & 20 & 1.7 & 6.6 & 5.6 & 4.6 & 3.3 \\
\hline 25-Feb & 33.6 & 28.5 & 23.5 & 16.8 & 20 & 1.7 & 6.6 & 5.6 & 4.6 & 3.3 \\
\hline 1-Mar & 33.6 & 28.5 & 23.5 & 16.8 & 20 & 1.7 & 6.6 & 5.6 & 4.6 & 3.3 \\
\hline 5-Mar & 33.6 & 28.5 & 23.5 & 16.8 & 20 & 1.7 & 6.6 & 5.6 & 4.6 & 3.3 \\
\hline 9-Mar & 33.6 & 28.5 & 23.5 & 16.8 & 20 & 1.7 & 6.6 & 5.6 & 4.6 & 3.3 \\
\hline 13-Mar & 33.6 & 28.5 & 23.5 & 16.8 & 20 & 1.7 & 6.6 & 5.6 & 4.6 & 3.3 \\
\hline 17-Mar & 30.5 & 25.9 & 21.4 & 15.3 & 20 & 1.7 & 6.0 & 5.1 & 4.2 & 3.0 \\
\hline 21-Mar & 30.5 & 25.9 & 21.4 & 15.3 & 20 & 1.7 & 6.0 & 5.1 & 4.2 & 3.0 \\
\hline
\end{tabular}




\begin{tabular}{|l|l|l|l|l|l|l|l|l|l|l|}
\hline 25-Mar & 29.7 & 25.3 & 20.8 & 14.9 & 20 & 1.7 & 5.8 & 5.0 & 4.1 & 2.9 \\
\hline 29-Mar & 28.1 & 23.9 & 19.7 & 14.1 & 20 & 1.7 & 5.5 & 4.7 & 3.9 & 2.8 \\
\hline 2- April & 26.3 & 22.3 & 18.4 & 13.1 & 20 & 1.7 & 5.2 & 4.4 & 3.6 & 2.6 \\
\hline 6- April & 24.4 & 20.7 & 17.1 & 12.2 & 20 & 1.7 & 4.8 & 4.1 & 3.4 & 2.4 \\
\hline 10- April & 20.1 & 17.1 & 14.0 & 10.0 & 20 & 1.7 & 3.9 & 3.3 & 2.8 & 2.0 \\
\hline 14- April & 18.4 & 15.7 & 12.9 & 9.2 & 20 & 1.7 & 3.6 & 3.1 & 2.5 & 1.8 \\
\hline
\end{tabular}

\subsection{Response of Tomato to Deficit Irrigation}

The result indicated in the Table 5 Marketable yield was significantly affected by the amount of water applied to the crop. The result showed that application of too low water reduced the yield of tomato, but applying zero deficits gives better yield. Higher marketable yield was 31.9 ton/ha obtained from treatment irrigated with full irrigation, while lower yield was 22.8ton/ha for treatment irrigated with $50 \%$ of ETc.

Unmarketable yield means that the fruits that were affected by pest attack, bird attack, rotten and under size. The result revealed that deficit irrigation treatment had no significant effect on unmarketable yield of tomato.

The total fruit yield showed that treatment with full irrigation has better yield and significantly difference from other treatment. Total yield in this treatment means that both marketable and unmarketable. In the treatment with full irrigation 43t/ha yield was obtained.

Table 5: Marketable yield

\begin{tabular}{|l|l|l|l|}
\hline TRT & MY (ton/ha) & UMY (ton/ha) & TY (ton/ha) \\
\hline Irrigation at 100\% Etc & $31.9 \mathrm{a}$ & 11.5 & $43.4 \mathrm{a}$ \\
\hline Irrigation at 85\% Etc & $25.0 \mathrm{~b}$ & 9.2 & $34.2 \mathrm{~b}$ \\
\hline Irrigation at 70\% Etc & $23.4^{\mathrm{b}}$ & 9.4 & $32.7 \mathrm{~b}$ \\
\hline Irrigation at 50\% Etc & $22.8^{\mathrm{b}}$ & 9.2 & $32 \mathrm{~b}$ \\
\hline Cv(\%) & 14.9 & 32.7 & 16.0 \\
\hline Lsd(0.05) & 3.2 & $\mathrm{NS}$ & 4.7 \\
\hline
\end{tabular}

$\mathrm{MY}=$ marketable yield, $\mathrm{UMY}=$ unmarketable yield, $\mathrm{TY}=$ total yield, ton $/$ ha $=$ tone per hectare, NS $=$ non-significant

\section{Water Use Efficiency}

The analysis of variance indicated that irrigation levels significantly $(\mathrm{p}<0.05)$ affected the irrigation water use efficiency of tomato. Table 6 shows that the highest mean value of irrigation water use efficiency was observed to be $12 \mathrm{~kg} / \mathrm{m} 3$ on irrigation with $85 \%$ ETc. and minimum mean value $(8.2 \mathrm{~kg} / \mathrm{m} 3)$ for treatments $\mathrm{T} 1(100 \% \mathrm{ETc}$.

Table 6: Water Use Efficiency

\begin{tabular}{|l|l|}
\hline TRT & WUE (kg/m3) \\
\hline Irrigation at 100\% Etc & $8.2^{\mathrm{c}}$ \\
\hline Irrigation at $85 \%$ Etc & $12^{\mathrm{ba}}$ \\
\hline Irrigation at $70 \%$ Etc & $10.9^{\mathrm{b}}$ \\
\hline
\end{tabular}




\begin{tabular}{|l|l|}
\hline Irrigation at 50\%Etc & $11^{\mathrm{a}}$ \\
\hline $\operatorname{Cv}(\boldsymbol{\%})$ & 19.1 \\
\hline Lsd(0.05) & 1.8 \\
\hline
\end{tabular}

TRT $=$ treatment, $\mathrm{WUE}=$ water use efficiency

\subsection{Economic Analysis of Deficit Irrigation with Tomato}

Cost benefit ratio for each treatments were analyzed and income was computed based on the current local market price of tomato at Humbo. At the time of harvest the market price of tomato was 10 birr per kg and the cost of irrigation water was $7 \mathrm{birr} / \mathrm{m}^{3}$ (by considering cost of drink water as the cost irrigation water). To analyze by the producer of dominance analysis, the treatments were set in their sort of increasing variable cost and their equivalent benefits were put aside. T4 and $\mathrm{T} 1$ showed the minimum and maximum variable cost respectively. Based on the current prices of tomato yield produced and input costs required for production, the economic analysis was carried out. The highest net income (242029 birr/ha) was obtained at T1 (full CWR throughout growing season) that received $395.3 \mathrm{~mm}$ seasonal irrigation water depth and the least net income (173831 birr/ha) was obtained at T3 (50\% of CWR deficit at mid stage) that received $197.6 \mathrm{~mm}$ depth of irrigation water. However, as it is indicated in table the largest MRR (1396\%) was acquired at T1 and the smallest MRR (247\%) was obtained at T2.

Table 8: Economic analysis of deficit irrigation on tomato

\begin{tabular}{|l|l|l|l|l|l|l|l|l|}
\hline Trt & $\begin{array}{l}\text { AW } \\
\text { (m } \mathbf{3} / \mathbf{h a})\end{array}$ & $\begin{array}{l}\text { Ay } \\
\text { (kg/ha) }\end{array}$ & $\begin{array}{l}\text { GI } \\
\text { (birr/ha) }\end{array}$ & $\begin{array}{l}\text { FC } \\
\text { (birr/ha) }\end{array}$ & $\begin{array}{l}\text { VC } \\
\text { (birr/ha) }\end{array}$ & $\begin{array}{l}\text { TC } \\
\text { (birr/ha) }\end{array}$ & $\begin{array}{l}\text { NI } \\
\text { (birr/ha) }\end{array}$ & $\begin{array}{l}\text { MRR } \\
(\%)\end{array}$ \\
\hline T4 & 1976 & 20520 & 205200 & 17400 & 13832 & 31232 & 173968 & - \\
\hline T3 & 2767 & 21060 & 210600 & 17400 & 19369 & 36769 & 173831 & D \\
\hline T2 & 3360 & 22500 & 225000 & 17400 & 23520 & 40920 & 184080 & 247 \\
\hline T1 & 3953 & 28710 & 287100 & 17400 & 27671 & 45071 & 242029 & 1396 \\
\hline
\end{tabular}

$\mathrm{AW}=$ Applied water, $\mathrm{Ay}=$ Adjusted yield, $\mathrm{GI}=$ Gross income, $\mathrm{FC}=$ Fixed cost, $\mathrm{Trt}=$ treatment, $\mathrm{VC}=$ Variable cost, $\mathrm{TC}=$ Total cost, $\mathrm{NI}=$ Net income, $\mathrm{MRR}=$ Marginal rate of return, $\mathrm{D}=$ Domination Therefore, the highest economic return was observed at T1 (100\% of CWR through growing season) with net income of 242029 birr/ha and MRR of $1396 \%$. The MRR tell us that the amount of additional income obtained for every 1 birr spent. Hence, T1 (100\% of CWR through growing season) acquired additional 13.96 birr for every 1 birr spent. The minimum acceptable marginal rate of return (MRR) should be between 50 and 100\% (CIMMYT, 1988).

\section{Conclusion and Recommendation}

\subsection{Conclusion}

Most of the farmers in Humbo Woreda depend on rain-fed agriculture. However, rainfall is very erratic, and drought occurs very frequently. Humbo Woreda is one of the droughts born woreda in Woliyta Zone. However, the proper management of irrigation water has received inadequate attention, while the cost incurred for constructing the small-scale irrigation schemes is much more. Efficient use of irrigation water using appropriate irrigation system and management is an important consideration in the drought prone areas of the region for improved crop production. 
One of the main challenges tackling both rain fed and irrigated agriculture is to improve WUE and sustainable water use for agriculture. The appropriate irrigation system and management in agriculture adopted to have significant impact on water saving. This strategy is introduced primarily to save water and improve WUE due to consumption of less water. However, it also delivers many other economic and social benefits to the society.

The conclusions drawn from this research are;

- A maximum fruit yield of $43.4 \mathrm{ton} / \mathrm{ha}$ and the highest economic return with net income of $242029 \mathrm{birr} / \mathrm{ha}$ was obtained under full irrigation i.e., when tomato was not subjected to any water stress.

- A deficit irrigation strategy applied at $85 \%, 70 \%$ of crop water requirement gives relatively better fruit yield than $50 \%$ of crop water requirement during growing season.

- Deficit irrigation with $50 \%$ of crop water requirement reduces the tomato yield significantly.

- Therefore, in area where enough water available, applying full water requirement through growing season is advisable. But, in water scarce areas of Humbo woreda applying 85\% and $70 \%$ of crop water requirement is advisable with a minimum reduction of yield.

- Even though the highest water use efficiency was obtained under 50\% deficit irrigation, the fruit yield was reduced.

\section{References}

[1] Ahmadi, S.H., Andersen, M.N., Plauborg, F., Poulsen, R.T., Jensen, C.R., Sepaskhah, A.R., Hansen, S (2010). Effects of irrigation strategies and soils on field grown potatoes: Yield and water productivity. Agricultural Water Management.

[2] Allen, .R. Pereira, L.A. Raes, .D. Simth, M., (1998). Crop Evapotranspiration Guidelines for Computing Crop Water Requirement. FAO Irrigation and Drainage Paper Number 56, FAO, Rome. and Sons. Inc. Toronto. Canada

[3] Andreas, P. and F. Karen., (2002). Crop Water Requirements and Irrigation Scheduling. Irrigation Manual Module 4. Harare.86P.

[4] Brady, N.C., and R.R. Weil, (2002). The nature and Properties of Soils. 13th ed. Perso

[5] Brouwer, C., Goffeau, A. and Heibloem, M., (1985). Irrigation Water Management: Introduction to irrigation. Training manual no. 1. FAO. Rome, Italy.

[6] Capra A., Consoli S., Scicolone B., (2008). Water management strategies under deficit irrigation. Journal of Agricultural Engineering, 4, 27-34.

[7] Cimmity (International Maize and Wheat Improvement Center). 1988. From Agronomic data to Farmer Recommendations: An Economics Training Manual. Completely Revised Edition. Mexico. D.F.

[8] Doorenbos, J. and Kassam, A. H. (1979). Yield Response to Water. FAO Irrig. And Drain. Paper No. 33, FAO, Rome, Italy. 193 p. Education Ltd., USA.

[9] Doorenbos, J. and W.O. Pruitt., (1977). Guidelines for predicting crop water requirements. FAO Irrig. Drain. Paper No. 24.FAO, Rome, Italy. 179 p.

[10] English MJ (1990) Deficit irrigation. I: Analytical framework. J Am Soc Civil Eng116: 399-412.

[11] Hillel, D., (2004). Introduction to environmental soil physics. University of Massachusetts, ELESIVIER Academic Press. New York. 493p.

[12] Kirda C (2000) Deficit irrigation scheduling based on plant growth stages showing water stress tolerance. Deficit Irrigation Practices. 
[13] Monteith JL, Unsworth MH. (1990). Principles of environmental physics, 2nd edn. London: Edward Arnold.

[14] Oweis, T. Zhang, H and Pala, M. (2000) Water use efficiency of rainfed and irrigated bread wheat in a Mediterranean environment. Agronomy Journal, 92, 231-238.

[15] Penman,H.L. (1948). Natural Evaporation from Open Water, Bare Soil and Grass, London, April,1948. The Royal Society of London. Series A, Mathematical and Physical, vol.193.pp120145.

[16] Shankara,N., Lidetde, J., Goffau, M., Hilmi, M. and VanDam, B., (2005). Cultivation of Tomato Production, Processing and Marketing. Singapore.

[17] Staney, W.C. and Yerima, B. (1992). Improvement of soil services for agricultural development: guidelines for soil sampling and fertility evaluation. Ministry of Natural Resources Development and Environmental Protection, Addis Ababa, Ethiopia.

*Corresponding author.

E-mail address: tamiratkifle26@ gmail.com 